\title{
Health accord side deals bad for Canada, say doctors
}

\author{
n Cite as: CMAJ 2017 January 30;189:E176-7. doi: 10.1503/cmaj.1095381
}

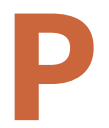

rogress in health care at the national level will only suffer if individual provinces or territories continue to broker side deals with the federal government, say concerned physicians. So far, three provinces have signed bilateral health agreements with the federal government: New Brunswick, Nova Scotia and Newfoundland.

"I understand that the Atlantic provinces want to ensure that they maximize health transfers, but I think it is a shame to waste the opportunity for a truly national vision for health care in Canada," Dr. Danielle Martin of the Women's College Hospital in Toronto, and past chair of Canadian Doctors for Medicare, said in an email. "I think that the distance between the parties was not that great, but the talks were rushed."

The current chair of Canadian Doctors for Medicare, Dr. Monika Dutt, expressed her dismay over the breakdown of national negotiations in an opinion piece in the Toronto Star. As a family physician in rural Nova Scotia, she wrote, she understood the pressure to obtain an infusion of funding for an older population in an area without a strong economy. Still, in the long term, health care for call Canadians may suffer "due to lack of cohesion" across the country.

"Atlantic Canada's jump into healthcare deals, while the rest of the country holds out for a better offer, raises many questions for doctors and patients," wrote Dutt. "Have those who committed quickly received a poorer deal? Will some provinces be rewarded for signing on while others punished for refusing the federal offer? Or will holdouts ultimately negotiate better arrangements? Will these debates eventually hurt patient care with people in some provinces receiving better

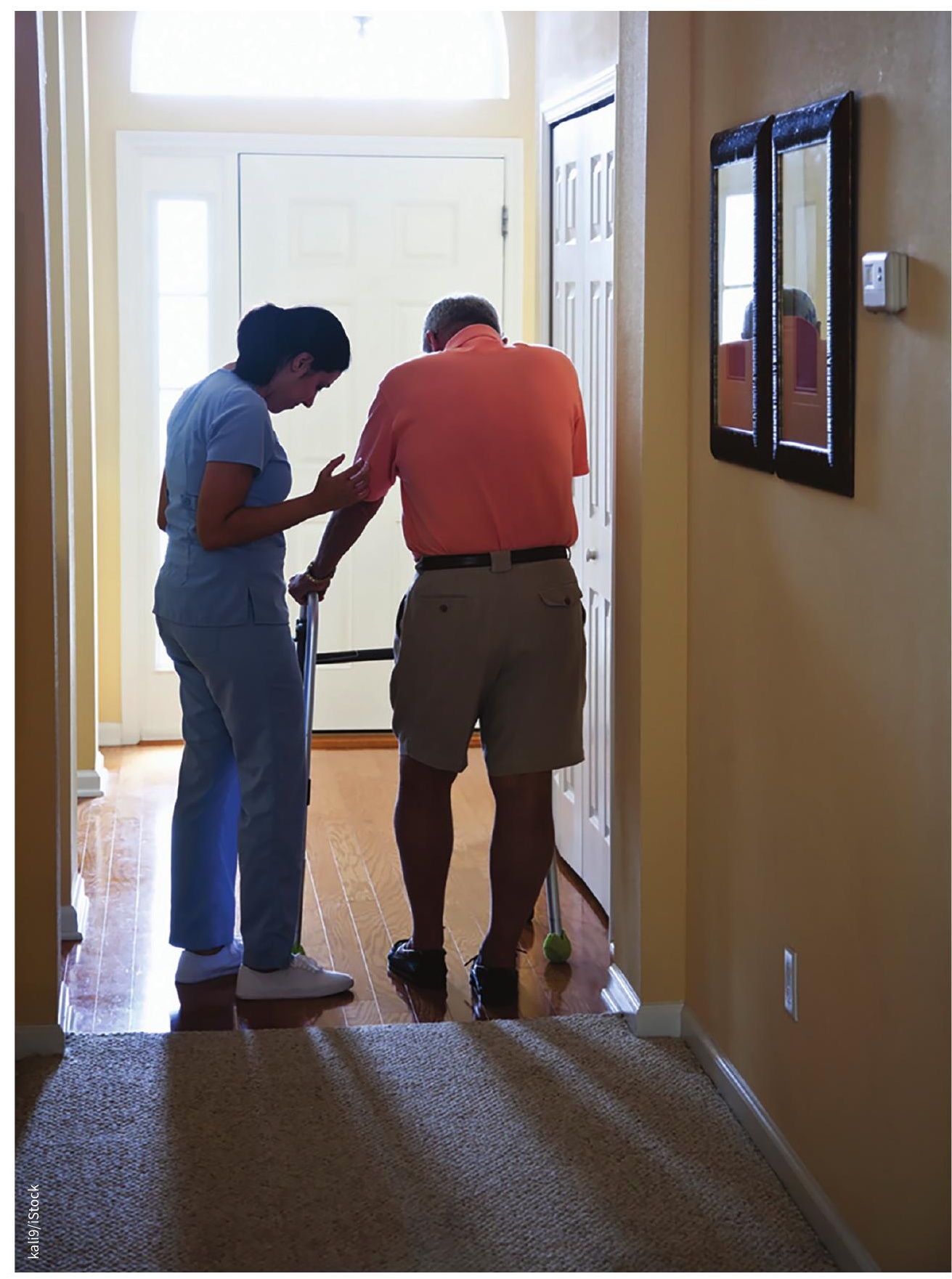

Three Atlantic provinces cut bilateral deals with the federal government that included funding for home care. 
publicly funded mental health services and home care?"

The Canadian Health Coalition referred to New Brunswick, the first province to cut a deal, as "the grinch that stole a national health accord." According to the coalition, New Brunswick weakened the ability of other provinces to negotiate a stronger health accord, and may have cost itself $\$ 659$ million if the side deal ends up being the catalyst for derailing the original provincial demands to maintain the current annual 6\% increase to the Canada Health Transfer. "All of us are at risk of seeing our public health care system significantly weakened if these types of bilateral arrangements continue," stated the coalition.

Several provincial politicians have also weighed in to express their disappoint- ment with the Atlantic provinces. Terry Lake, health minister for British Columbia, stated that he was sad to see the federal government "cutting side deals instead of dealing with all provinces on a transparent and multilateral basis." Charles Sousa, Ontario's finance minister, suggested that individual bilateral deals would create a "patchwork system" of health care across Canada.

The 10 provinces and territories that haven't made side deals sent a letter to the federal government on Jan. 3 requesting that negotiations on a national health accord be renewed. "Any lasting national agreement on the future of health care requires the federal government to be a reliable and lasting partner in supporting delivery of these critical services," the letter reads.
The splintering of the national stand of provinces and territories began on December 22, when New Brunswick announced a 10-year, \$230 deal that included funding dedicated to home care and mental health. The next day, Nova Scotia and Newfoundland announced similar deals. Nova Scotia will receive $\$ 157$ million for home care and $\$ 130.8$ million for mental health. Newfoundland will receive $\$ 87.7$ million for home care and $\$ 73$ million for mental health. These provinces will also receive annual Canada Health Transfer increases of at least 3\% (possibly more, depending on gross domestic product growth) and many will receive added benefits if other provinces negotiate better deals.

Roger Collier, CMAJ 